\title{
EFFECTS OF THE STRIDE LENGTH ON THE GAIT AND INTRA-LIMBS COORDINATION OF HEALTHY CHILDREN AGED 3 TO 6
}

\author{
Yuguo FENG ${ }^{1}$, Bo XU², Jin ZHOU ${ }^{2 *}$ \\ ${ }^{1}$ College of Applied Technology of Xihua University, No. 999 Jinzhou Road, Jinniu District, Chengdu City, 17345831@qq.com \\ ${ }^{2}$ National Engineering Laboratory for Clean Technology of Leather Manufacture, Sichuan University, No. 24, South Section of \\ First Ring Road, Wuhou District, Chengdu, zj_scu@scu.edu.cn
}

Received: 11.09 .2018

Accepted: 17.01.2019

https://doi.org/10.24264/Ifj.19.1.1

\section{EFFECTS OF THE STRIDE LENGTH ON THE GAIT AND INTRA-LIMBS COORDINATION OF HEALTHY CHILDREN AGED 3 TO 6}

ABSTRACT. Body motion adjusts while the stride lengths changes, but few studies report those influences on the gait mechanism and intralimbs coordination of children; therefore, the purpose of our study was to evaluate the gait mechanism and intra-limbs coordination of healthy children aged 3-6 under stride length adjusting, so as to add the knowledge of motor development of healthy children. Forty-five healthy children and ten adults walked on a $6 \mathrm{~m}$ walkway at three stride lengths (short stride (SS), normal stride (NS) and long stride (LS)) and key kinematical parameters such as Euler angles and angular velocities were first recorded by CodaMotion 3D measure system; and then those two variables were applied to calculate the continuous relative phase (CPR) which specified coordination in the knee and ankle. Results showed that when transferring from short stride to normal stride long stride, children were to deal with by increasing stride length, Froude number, swing phase, and decreasing frequency. However, there were no significant differences between SS and LS in kinematical parameters; meanwhile, those significant variations were not found between age groups. In terms of intra-limb's coordination, there were no significant differences in values of relative phases within and between age groups. In conclusion, as early as age 3 , young toddlers have already mastered the basic ability in adjusting gait while walking.

KEY WORDS: child development, gait, intra-limbs coordination, long stride, short stride

\section{INFLUENTA LUNGIMII PASULUI ASUPRA MERSULUI ŞI COORDONĂRII MEMBRELOR INFERIOARE LA COPII SĂNĂTOŞI CU VÂRSTA ÎNTRE 3 ŞI 6 ANI}

REZUMAT. Mişcarea corporală se reglează pe măsură ce se modifică lungimea paşilor, însă puţine studii raportează aceste influenţe asupra mecanismului mersului şi coordonării membrelor inferioare la copii; prin urmare, scopul studiului nostru a fost de a evalua mecanismul mersului şi coordonarea membrelor inferioare la copii sănătoşi cu vârste cuprinse între 3 şi 6 ani, în condiţiile ajustării lungimii paşilor, pentru a contribui la cunoştinţele privind dezvoltarea motorie a copiilor sănătoşi. Patruzeci şi cinci de copii sănătoşi şi zece adulţi au mers pe o platformă de $6 \mathrm{~m}$ efectuând paşi de trei lungimi (pas scurt (SS), pas normal (NS) şi pas lung (LS)), iar parametri cinematici cheie, cum ar fi unghiurile Euler și vitezele unghiulare, s-au înregistrat prin sistemul de măsurare CodaMotion 3D; apoi acele două variabile au fost aplicate pentru a calcula faza relativă continuă (CPR) care specifică coordonarea la nivelul genunchilor şi gleznei. Rezultatele au arătat că, atunci când trec de la un pas scurt la un pas normal şi lung, copiii au trebuit să mărească lungimea pasului, numărul Froude, faza de balans şi să scadă frecvenţa. Cu toate acestea, nu au existat diferenţe semnificative între SS şi LS privind parametrii cinematici; nu s-au identificat aceste variaţii semnificative între grupele de vârstă. În ceea ce priveşte coordonarea membrelor inferioare, nu au existat diferenţe semnificative între valorile fazelor relative în cadrul grupelor de vârstă şi între acestea. În concluzie, încă de la vârsta de 3 ani, copiii au deprins deja abilitatea de bază de a ajusta lungimea paşilor în timpul mersului.

CUVINTE CHEIE: dezvoltarea copilului, mers, coordonare intra-membre, pas lung, pas scurt

\section{L'INFLUENCE DE LA LONGUEUR DES FOULÉES SUR LA MARCHE ET LA COORDINATION INTRA-MEMBRE CHEZ LES ENFANTS EN BONNE} SANTÉ ÂGÉS DE 3 À 6 ANS

RÉSUMÉ. Les mouvements du corps s'adaptent à mesure que la longueur des foulées change, mais peu d'études ont rapporté ces influences sur le mécanisme de la marche et la coordination intra-membre chez les enfants; notre étude visait donc à évaluer le mécanisme de la marche et la coordination intra-membre chez les enfants en bonne santé âgés de 3 à 6 ans en ajustant la longueur des foulées afin de contribuer à la connaissance sur le développement des capacités motrices des enfants en bonne santé. Quarante-cinq enfants et dix adultes en bonne santé ont marché sur une passerelle de 6 mètres en faisant des foulées de trois longueurs (foulée courte (SS), foulée normale (NS) et foulée longue (LS)), et les principaux paramètres cinématiques, les angles d'Euler et les vitesses angulaires, ont été enregistrés à l'aide du système de mesure 3D CodaMotion; ensuite, ces deux variables ont été appliquées pour calculer la phase relative continue (CPR) qui spécifie la coordination du genou et de la cheville. Les résultats ont montré que pour passer d'une foulée courte à une foulée normale et longue, les enfants devaient augmenter la longueur du pas, le nombre de Froude, la phase de la balance et diminuer la fréquence. Cependant, il n'y avait pas de différences significatives entre SS et LS en ce qui concerne les paramètres cinématiques; ces variations significatives entre les groupes d'âge n'ont pas été identifiées. En ce qui concerne la coordination intra-membre, il n'y avait pas de différences significatives entre les valeurs des phases relatives dans les groupes d'âge et entre celles-ci. En conclusion, depuis l'âge de 3 ans, les enfants ont déjà appris la capacité de base pour ajuster la longueur des foulées dans la marche.

MOTS CLÉS : développement de l'enfant, marche, coordination intra-membre, foulée longue, foulée courte.

\footnotetext{
* Correspondence to: Assoc. Prof. Dr. Jin ZHOU, National Engineering Laboratory for Clean Technology of Leather Manufacture, Sichuan University; Chengdu 610065, P. R. China; Fax: 008613880467494, email: zj_scu@scu.edu.cn.
} 


\section{INTRODUCTION}

Human's motor function is a complex system; it involves series components closely cooperated to complete a movement, such as muscles, joints and bones. Degree of freedom (DOF) [1-2] decides mode of nervous system to control muscles and bones; meanwhile, motor coordination [3-4] is a crucial mechanism to guarantee the efficiency and rhythms of walking. There is a specific route of this process: nervous system detects signals from environmental changes that impact the body; then coordinates the actions of muscles and bones by translating the signals into simple instructions that muscles and bones can accept. When the normal stride mode is interfered, for instance, it will directly lead to a new combination of DOF in NMS. So, by observing the variations while transferences would highlight the inner development mechanism in motion of healthy children. This study will focus on the transference from normal stride (NS) to long stride (LS) and short stride (SS) independently, so as to explore the ability of children aged 3-6 in dealing with those modifications.

Current studies reported that while environmental constraints change, stride length, step frequency and speed remained constant range [5] (such as backward walking, crossing obstacle and eyes-closed walking); whereas, patients of cerebral palsy, Parkinsonian syndrome and stroke, individuals would modulate their stride length to maintain balance [6]. LS and SS have been studied. Varraine et al. [7] found that adults would maintain balance in LS and SS by using different stance and swing phases. Huang et al. [8] studied influence of different stride-frequencies on spine stability and they

\section{EXPERIMENTAL}

\section{Subjects}

Table 1: Individual Parameters for Five Groups

\begin{tabular}{cccccc}
\hline & & & & & \\
& Age 3 group & Age 4 group & Age 5 group & Age 3 group 6 & Adult group \\
\hline $\mathrm{N}$ & 10 & 10 & 12 & 13 & 10 \\
Mean Age (years) & $3.2 \pm 0.3$ & $4.4 \pm 0.3$ & $5.1 \pm 0.2$ & $6.0 \pm 0.1$ & $34.5 \pm 9.8$ \\
Mean Weight (kg) & $15.1 \pm 1.7$ & $17.4 \pm 3.3$ & $19.1 \pm 2.8$ & $19.2 \pm 2.4$ & $58.3 \pm 6.7$ \\
Mean Height (cm) & $96.2 \pm 4.3$ & $102.7 \pm 5.2$ & $107.9 \pm 4.6$ & $112.3 \pm 4.8$ & $166.4 \pm 7.5$ \\
Mean BMI & $16.2 \pm 0.9$ & $16.4 \pm 2.3$ & $16.34 \pm 1.3$ & $15.2 \pm 1.1$ & $20.9 \pm 1.7$ \\
Mean Leg length (cm) & $52.9 \pm 2.5$ & $54.3 \pm 2.8$ & $62.2 \pm 2.3$ & $64.1 \pm 2.4$ & $99.8 \pm 7.3$ \\
\hline
\end{tabular}

summarized that LS with lower frequency significantly affected the phase changing of spine. Further, Young et al. [9] evaluated the varied width and length of steps on the trunk stability and suggested that SS had significant effects on the stability of trunk motions. However, Hak et al. [10] indicated that stride length adjusting modified the margins of stability, but it couldn't affect the local dynamic stability.

Current knowledge implied that stride length would significantly affect gait and intralimbs coordination. Bernstein [1] pointed out that knowledge and experience have impact on the development of motor coordination. However, few qualified studies have showed when does motor coordination mature to cope with stride length adjustment. Since children aged 3-6 [1112] were in a stage of an important first transition with regard to the amount of postural sway occurring, we could question that are there any differences in gait of healthy children between LS and SS, or is there any variation in intra-limbs coordination between LS and SS? Are there any inter-age differences in both gait and intra-limbs coordination?

Therefore, concerning with those questions, the purpose of our study was to evaluate the gait mechanism and intra-limbs coordination of healthy children aged 3-6 under stride length adjusting, so as to add the knowledge of motor development of healthy children. With respect to the first and second research question, we hypothesized that children would perform different gait and intra-limbs coordination between LS and SS. With respect to the third research question, we hypothesized that inter-age differences would exist both in gait and intra-limbs coordination. 
Forty-five healthy children and ten adults were recruited and divided into five groups of $3,4,5,6$, and Adult. The characteristics of these groups are reported in Table 1 . All subjects did not have orthopedic or neurological disorders.

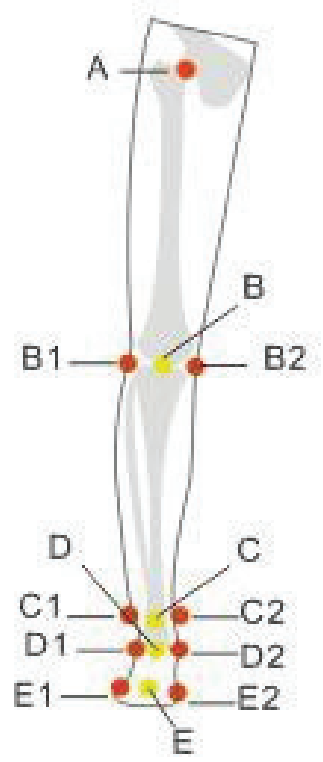

a
All the measures were executed after the study details were introduced to the children's parents and with their formal approvals. Moreover, all the measurements and procedures followed the principles of Helsinki Declaration.

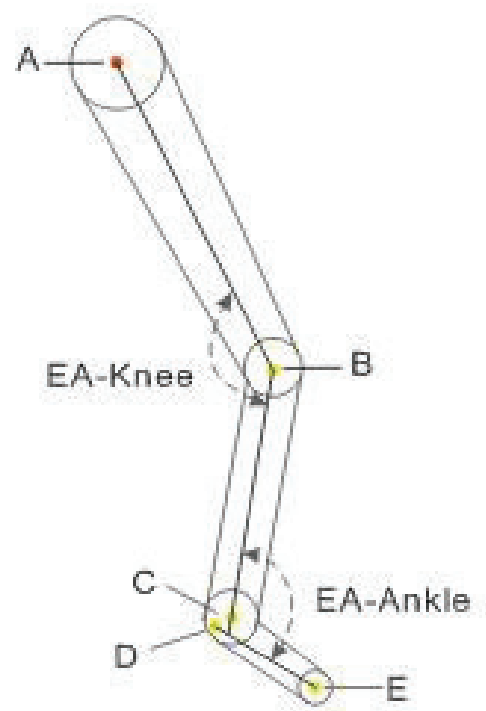

b

Figure 1. Markers location and Euler Angles for lower limbs

(a) Position of the landmark of elevation view; (b) Euler Angles of lateral view

\section{Data Collection Protocol}

The marking patterns of joints were divided into two types: anatomic markers and virtual markers (obtained by Odin software (V1.02, Charnwood Dynamics Ltd., United Kingdom)) (Figure 1. a). Details of anatomic markers included: marker ' $A$ ' represent a point of the anterior superior iliac spine; marker ' $\mathrm{B} 1$ ' and 'B2' are the lateral and medial prominences of the distal points of thigh; ' $\mathrm{C} 1$ ' and ' $\mathrm{C} 2$ ' imply the lateral and medial prominences of ankle; 'D1' and ' $\mathrm{D} 2$ ' are the lateral and medial extremities of the heel; 'E1' and 'E2' indicate the $5^{\text {th }}$ and $1^{\text {st }}$ MTH. Virtual markers included the central points of knee, ankle, heel, and forefoot, named B, C, D, $E$ respectively. Motion in the sagittal plane, such as flexion/extension of the knee $(\vartheta$ (EA-Knee) / $\omega$ (EA-Knee)) and ankle ( $\vartheta$ (EA-Ankle) / $\omega$ (EAAnkle)) were showed in Figure 2. a.

Subjects walked at their own selected speed on the track, then the average step length was calculated, which was defined as the normal step length of each age group $(36 \mathrm{~cm}, 44 \mathrm{~cm}$,
$60 \mathrm{~cm}, 70 \mathrm{~cm}$ and $90 \mathrm{~cm}$ for age 3, 4, 5, 6 and Adult). Two stride lengths were provided: LS and SS. LS was defined as that participants walked with $150 \%$ step length of the normal walking $(54 \mathrm{~cm}, 66 \mathrm{~cm}, 80 \mathrm{~cm}, 105 \mathrm{~cm}$ and $135 \mathrm{~cm}$ for age 3 , 4, 5, 6 and Adult); while SS was that participants walked with $50 \%$ step length of the normal walking [13-14] $(18 \mathrm{~cm}, 22 \mathrm{~cm}, 30 \mathrm{~cm}, 35 \mathrm{~cm}$ and $45 \mathrm{~cm}$ for age 3, 4, 5, 6 and Adult). LS and SS were randomly assigned to children in the measure.

Subjects were asked to warm up for 60 seconds firstly, and then they chose their own preferred speed and walked along a $6 \mathrm{~m}$ walkway (Figure 2). The walking path was composed of two parts: the first one was $3 \mathrm{~m}$ normal walking area, and the last $3 \mathrm{~m}$ was the stride changing area. Two Codamotion cameras were aligned on both sides of the $6 \mathrm{~m}$ walking track, placing at an angle of $160^{\circ}$. Five successful walking trials for each condition were used for further analysis. A successful trial included five consecutive foot strikes with full-marker-visibility. 


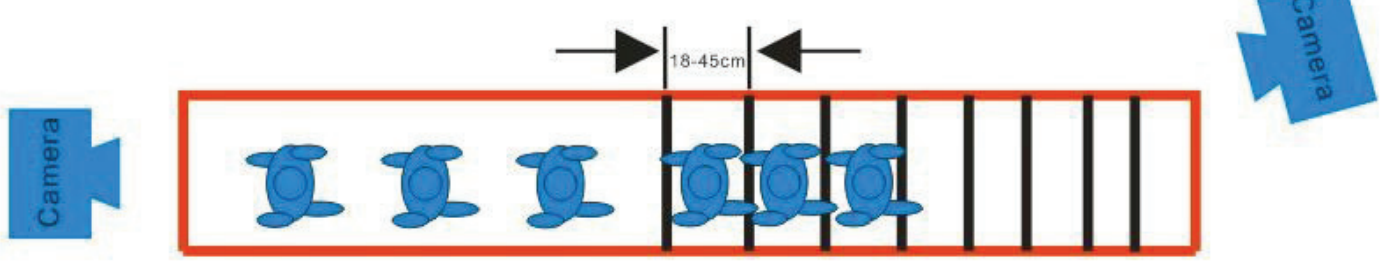

a

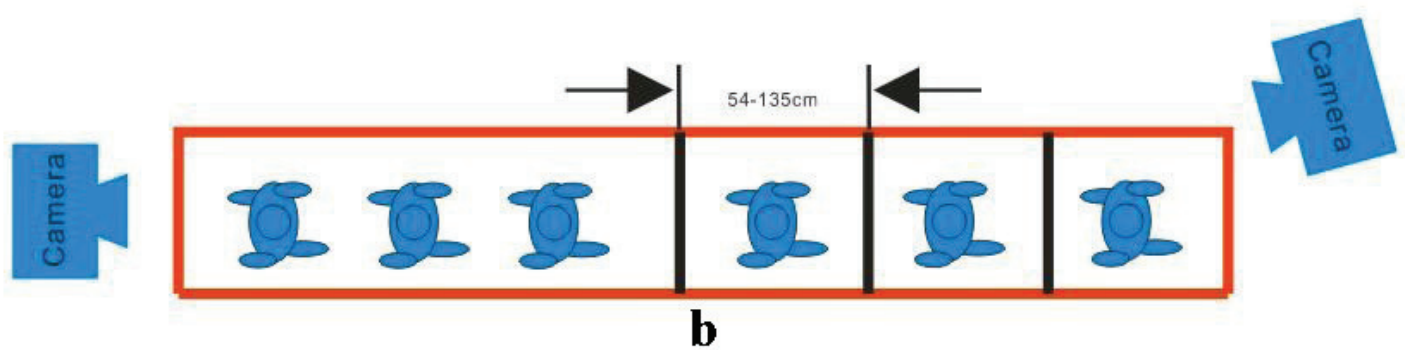

Figure 2. Definition of the LS and SS

(a) Walking sketch map of SS; (b) Walking sketch map of LS

\section{Data Processing}

TSP (tempero-spatial parameters) were processing first, which included frequency (steps/time), Froude number $\left(\mathrm{Fr}=V^{2} / \mathrm{g} \cdot \mathrm{L} \quad(V\right.$ : velocity, g: acceleration of gravity, $L$ : leg length), stride time (the interval of two times forefoot contacting phase of right foot), percentage of stance duration (the percentage of right foot supporting phase during gait cycle) and percentage of swing duration (the percentage of right foot lifting phase during gait cycle).

The time-courses of the Euler angle ( $\vartheta$ ) and angular velocity $(\omega)$ of lower-limb were calculated in the Odin software with respect to the vertical in the sagittal plane $(200 \mathrm{~Hz})$. and they were filtered using a FIR filter with cut-off of $6 \mathrm{~Hz}$. Then three-times-spline-curve was used for interpolation calculus to create a 100-point time-normalized gait cycle (GC) [15]. Finally, the mathematical model of the continuous relative phase $\left(\vartheta_{C R P}(A-K)\right)$ was computed between the ankle and knee, and it was used to analyze the timing of the interlimb movements. The calculation procedures were as follows: first, the Euler angle $(\vartheta)$ and angular velocity $(\omega)$ were normalized into $\vartheta$ and $\omega$ (Eqs. (1) and (2)). Second, the point phase angle (PA) was computed according to (Eqs. (3)). Finally, the $\vartheta_{C R P}$ (A-K) was resolved (Eqs. (4)). Coordination stability was described by standard deviation (SD) of CRP, and the dispersion degree of parameters was characterized by Range.

$$
\begin{gathered}
\dot{\theta}=2\left[\frac{\theta-\min (\theta)}{\max (\theta)-\min (\theta)}\right]-1 \text { (Eps. 1) } \\
\dot{\omega}=\left[\frac{\omega}{\max (|\omega|)}\right] \text { (Eps. 2) } \\
\varphi \text { (i) }=\tan ^{-1}\left[\frac{\omega(i)}{\overline{\frac{\omega}{\theta}}}\right], i=1,2, \ldots, n \text { (Eps. 3) } \\
\theta_{C R P} \text { (i) }=\left|\varphi_{1}(i)-\varphi_{2}(i)\right| \text { (Eps. 4) }
\end{gathered}
$$

\section{Statistical Analysis}

Normal distribution was tested by One Sample K-S model and the results indicate that all data obey the normal distribution. Gait differences between LS and SS were assessed using Paired-Samples $T$ Test, and inter-age differences were assessed by One-Way ANOVA. All the statistical models were executed under SPSS 16 with the significance level of 0.05 and confidence interval of $95 \%$. The coordination stability of joint was described by standard deviation (SD), and the dispersion degrees of parameters was characterized by Range. 


\section{RESULTS}

\section{Character of TSP}

Compared with SS, LS showed a longer stride time, larger Froude number (according to Figure 3), shorter stance duration and lower frequency. But stride time and stance duration of both gait decreased gradually with the increasing of age. In addition, all parameters were close to adult level gradually, except frequency and Froude number.
In the two walking tasks, the results of variance analysis of inner-age groups showed that there were significant differences in each age of $4-6$ in terms of stride time $(p<0.05)$, and the Froude number of all groups were different, except with that of age 6 . What's more, the swing duration in age 4, 5 and adult groups also revealed remarkable differences $(p<0.05)$. According to the results of variance analysis of inter-age groups, the differences between children and adult mainly existed in the frequency of $L S(p=0.002<0.05)$ and the stride length of $L S(p=0.003<0.05)$.
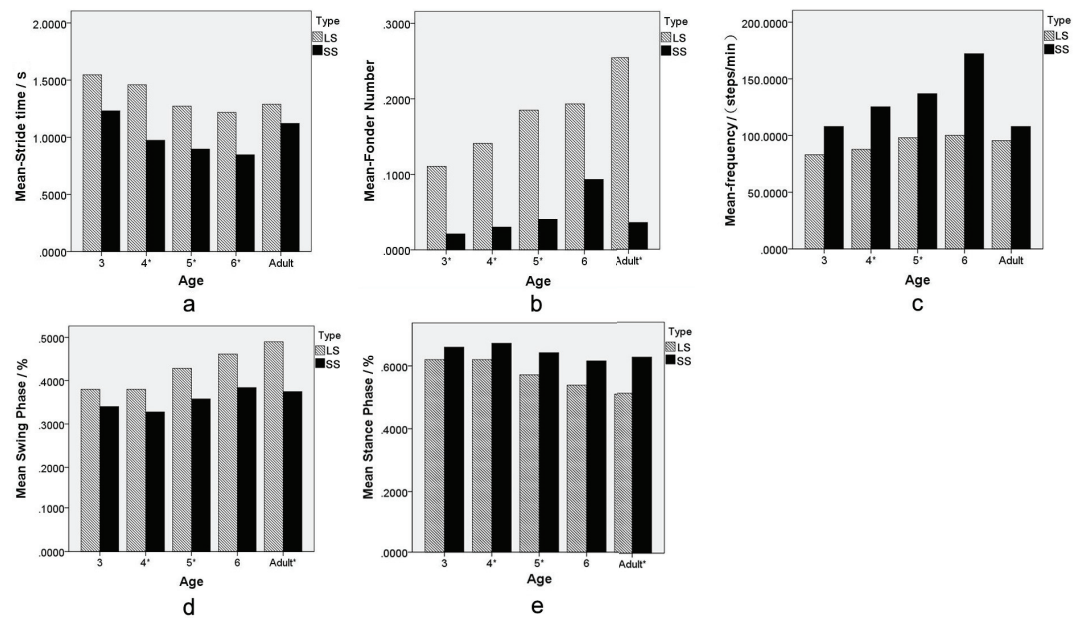

Figure 3. Portraits of the TSP

(a) Mean stride time; (b) Mean Froude Number; (c) Mean frequency;

(d) Mean swing phase; (e) Mean stance phase.

* significant difference between LS and SS within groups

\section{The Relationship between the Normalized} Euler Angles and Angular Velocities of Joints

The relationship between the normalized Euler angles and angular velocities of all joints were observed for both gait (Figure 4). In both joints, there was no difference ( $p>0.05$ for all) between the LS and SS of all inner-age groups. Nevertheless, comparison between different age groups, ankle joint SD of adult was significantly higher than that of children aged 3-4 under LS (Adult vs. age $3, p=0.021<0.05$, Adult vs. age 4 , $\mathrm{p}=0.04<0.05)$. 

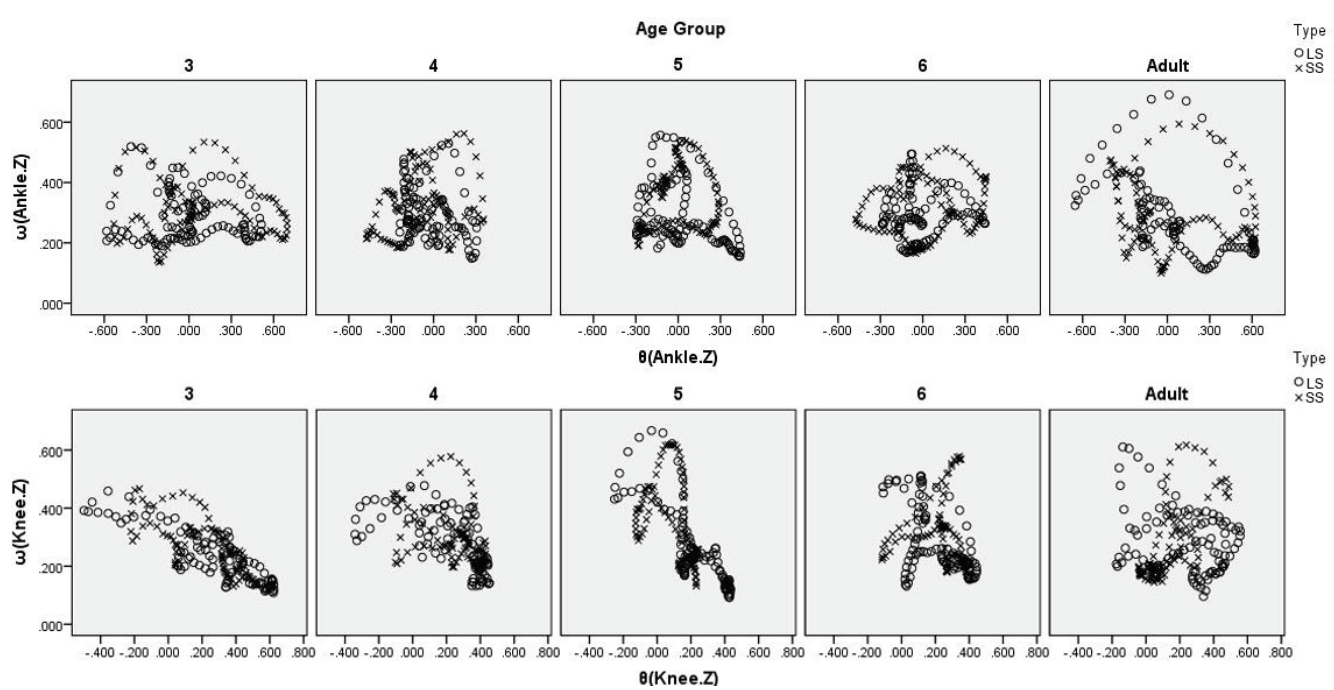

Figure 4. Portraits of the relationship between the standard Euler Angles and velocities of knee and ankle joints

\section{Intra-limb Coordination of Each Joint}

According to (Figure 5), the $\vartheta_{C R P}(A-K)$ of adults under LS was higher than that under SS during the period of heel contact ( $1 \%-17 \%$ GC) and toe off (41\%-61\% GC). Then it decreased dramatically in the swing phase $(71 \%-100 \%$
GC). Results of Range and SD showed that there was no significant difference in inner-age groups ( $p>0.05)$, except with those of age 6 ( $p=0.007<0.01$ for SD; $p=0.039<0.05$ for Range). Meanwhile, there was no significant difference in Range and SD between different age groups ( $p>0.05$ for all).

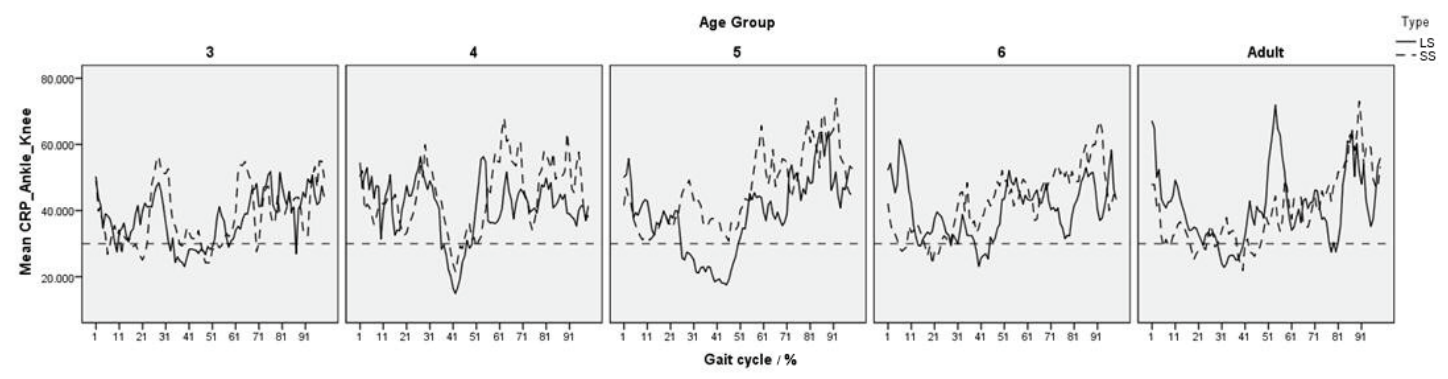

Figure 5. Portraits of continuous relative phase between the Knee and Ankle Joints

\section{DISCUSSION}

The purpose of our study was to evaluate the gait mechanism and intra-limbs coordination of healthy children aged 3-6 under stride length adjusting, so as to add the knowledge of motor development of healthy children. Results showed that when transferring from short stride to normal stride long stride, children were to deal with by increasing stride length, Froude number, swing phase, and decreasing frequency. However, there were no significant differences between SS and LS in kinematical parameters; meanwhile, those significant variations were not found between age groups. In terms of intralimb's coordination, there were no significant differences in values of relative phases within and between age groups.

Hak et al. [10] pointed out that increasing stride length would lead to higher speed, and lower frequency. Our results supported this idea, all groups may increase Froude number and decrease stride frequency to response the conversion of SS to LS. The above results showed that length adjustment could significantly affect TSP. In addition, there was no significant difference in TSP between adults and children, which indicated that children's ability to control stride length had basically matured at the age of 3 .

Varraine et al. [7] evaluated the two controlling mechanisms of LS and SS. On one 
hand, the activity of hip extensor-biceps femoris of the SSing leg would increase so as to finish leg-swing in advance, thus shortening the swingduration during SS. On the other hand, the controlling mechanism was opposite during LS. The activity of ankle extensor muscles-soleus, and the hip extensors-biceps of ipsilateral leg increased to improve propulsive force in stance stage. Meanwhile there was also an increasing activity in hip and ankle flexors-rectus femoris and tibialis anterior during the ipsilateral swing stage for maintaining flexion-state of ipsilateral leg so that the foot would land later. Thereby longer swing-duration would be obtained. Our findings are consistent with Varraine et al. [7] who reported that swing-duration increased significantly from SS to LS. Moreover, swingduration of children would gradually be close to that of adults with age increasing, both showed in LS and SS. It is also confirmed by Perry et al. [16] who suggested that the foot development was normally low-energy trend.

In terms of the relationship between Euler angles and velocities in joints of knee and ankle, no significant differences were observed in most parameters across age groups. It was in agreement with the results of Sutherland et al. [17] who reported that the activity of intra-limbs in children aged 3-4 was similar to that in adults. Furthermore, Ounpuu et al. [18] demonstrated that gait kinematic parameters of children aged 5-16 were consistent with those of adults. Based on the above results, it would appear that the fundamental basis for the adaptation of LS and SS is fully achieved at 3 years.

The differences of $\vartheta_{C R P}(A-K)$ were discovered during the period of heel contact (1\%$17 \% \mathrm{GC})$, toe off ( $41 \%-61 \% \mathrm{GC})$, and swing phase (71\%-100\% GC) between LS and SS, which may be due to the longer and faster stride. During heel contacting, due to high speed, ankle-knee joint would absorb more ground reaction force. As for toe-off, intra-limbs needed to achieve higher forward moving force. And during swing phase, body needed to prolong the contacting time of swing leg to obtain body compensation. Our results were confirmed by Huang et al. [8] who found that increasing stride length (with lower frequency) led to larger spinal rotations, larger thorax-pelvis relative phase and lower pelvis-leg relative phase. Our study was also confirmed by Varraine et al. [7] who reported the control systems of LS and SS.

Our findings of $\vartheta_{C R P}(A-K)$ also showed that there was no inter-age difference under both gaits. This was proved by Warren et al. [19] who pointed out that shortening and widening step length didn't affect walking stability. Danion et al. [20] reported that gait was a very stable behavior, although gait parameters changed. That is to say, the basic principle of intra-limbs coordination had already formed at the age of 3 .

Besides, there are some limitations in our study. (1) Children chose their preferred walking speed during measurement; (2) Markers were set on tight clothing rather than skin. This would cause movement of the marker while walking; (3) Broad categories of age were chosen in our study, regardless of details of development within each age; (4) Only the right-side limbs were studied because of the markers limitation of our system.

\section{CONCLUSIONS}

In conclusion, as early as age 3, young toddlers have already mastered the basic ability in adjusting gait while walking.

\section{Acknowledgements}

The study was supported by Project of Education Department of Sichuan province, China (18ZB0569) and National Natural Science Foundation of China (31700813).

\section{REFERENCES}

1. Bernstein, N.A., The coordination and regulation of movement, New York: Pergamon Press, 1967.

2. Zernicke, R.F., Smith, J.L., Biomechanical Insights into Neural Control of Movement, Handbook of Physiology, New York: Oxford University Press, 1996, 293-330, http://doi. org/10.1002/cphy.cp120108.

3. Scholz., J.P., Dynamic pattern theory-some implications for therapeutics, Phys Ther, 1990, 70, 12, 827, http://doi.org/10.2307/1510393.

4. Newell, K.M., Coordination, Control and Skill, Adv Psychol, 1985, 27, 295-317, http://doi. org/10.1016/S0166-4115 (08) 62541-8.

5. Winter, D.A., Kinematic and kinetic patterns in human gait: Variability and compensating effects, Hum Mov Sci, 1984, 3, 1, 51-76, 
http://doi.org/10.1016/0167-9457 90005-8.

6. Patla, A.E., Armstrong, C.J., Silveira, J.M., Adaptation of the muscle activation patterns to transitory increase in stride length during treadmill locomotion in humans, Hum Mov Sci, 1989, 8, 1, 45-66, http://doi. org/10.1016/0167-9457 (89) 90023-7.

7. Varraine, E., Bonnard-Mpailhous, J., Intentional on-line adaptation of stride length in human walking, Exp Brain Res, 2000, 130, 2, 248-257, http://doi.org/10.1007/ s002219900234.

8. Huang, Y., Meijer, O.G., Lin, J., Bruijn, S.M., Wu, W., Lin, X., Hu, H., Huang, C., Shi, L., Van, J.H., The effects of stride length and stride frequency on trunk coordination in human walking, Gait Posture, 2010, 31,4, 444-449, http://doi.org/10.1016/j. gaitpost.2010.01.019.

9. McAndrew Young, P.M., Dingwell, J.B., Voluntarily Changing Step Length or Step Width Affects Dynamic Stability of Human Walking, Gait Posture, 2012, 35, 3, 472-477, http://doi.org/10.1016/j. gaitpost.2011.11.010.

10. Hak, L., Han, H., Beek, P.J., Van, J. H., Steps to Take to Enhance Gait Stability: The Effect of Stride Frequency, Stride Length, and Walking Speed on Local Dynamic Stability and Margins of Stability, Plos One, 2013, 8, 12, e82842, http://doi.org/10.1371/journal. pone.0082842.

11.Wolff, D.R., Rose, J., Jones, V.K., Bloch, D.A., Oehlert, J.W., Gamble, J.G., Postural balance measurements for children and adolescents, J Orthop Res, 2010, 16, 2, 271, http://doi. org/10.1002/jor.1100160215.

12. Verbecque, E., Costa, P.H.L. da., Meyns, P., Desloovere, K., Vereeck, L., Hallemans, A., Age-related changes in postural sway in preschoolers, Gait Posture, 2016, 44, 116-122, http://doi.org/10.1016/j. gaitpost.2015.11.016.

13. Hof, A.L., Scaling gait data to body size, Gait Posture, 1996, 4, 3, 222-223, http://doi. org/10.1016/0966-6362 (95) 01057-2.

14. Zhou, J., Song, Y., Xu, B., Chen, W., Features of plantar pressure distribution of Chinese children aged between two and eleven, Leather and Footwear Journal, 2014, 14, 3,
135-146, http://doi.org/10.24264/Ifj.14.3.1.

15. Clark, J.E., Phillips, S.J., The development of intralimb coordination in the first six months of walking, Adv Psychol, 1991, 81, 245-257, http://doi.org/10.1016/S0166-4115 60769-4.

16. Perry, S.D., Radtke, A., Goodwin, C.R., Influence of footwear midsole material hardness on dynamic balance control during unexpected gait termination, Gait Posture, 2007, 25, 1, 94-98, http://doi.org/10.1016/j. gaitpost.2006.01.005.

17. Sutherland, D.H., Olshen, R., Cooper, L., Woo, S.L., The development of mature gait, J Bone Joint Surg Am, 1980, 62, 3, 336-353, http:// doi.org/10.1016/S0966-6362 (97) 00029-5.

18. Ounpuu, S., Gage, J.R., Davis, R.B., Threedimensional lower extremity joint kinetics in normal pediatric gait, J Pediatr Orthop, 1991, 11, 3, 341, http://doi.org/10.1097/01241398199105000-00012.

19. Warren, W.H., Young, D.S., Lee, D.N., Visual control of step length during running over irregular terrain, J Exp Psychol Hum Percept Perform, 1986, 12, 3, 259-266, http://doi. org/10.1037/0096-1523.12.3.259.

20. Danion, F., Varraine, E., Bonnard, M., Pailhous, J., Stride variability in human gait: The effect of stride frequency and stride length, Gait Posture, 2003, 18, 1, 69-77, http://doi. org/10.1016/S0966-6362 (03) 00030-4.

(C) 2019 by the author(s). Published by INCDTPICPI, Bucharest, RO. This is an open access article distributed under the terms and conditions of the Creative Commons Attribution license (http:// creativecommons.org/licenses/by/4.0/). 